\title{
Komunikasi Interpersonal Peserta Didik Kelas XI SMA Negeri 2 Padang Cermin Kabupaten Pesawaran
}

\author{
Yahya AD, Winarsih
}

Dosen Fakultas Tarbiyah dan Keguruan, IAIN Raden Intan Lampung

Diterima: 2 Januari 2016. Disetujui: 12 Februari 2016. Dipublikasikan: Mei 2016

\begin{abstract}
Abstrak: Komunikasi merupakan bentuk tingkah laku seseorang baik verbal maupun non-verbal yang ditanggapi oleh orang lain. Setiap bentuk tingkah laku yang mengungkapkan pesan tertentu, sehingga juga merupakan sebentuk komunikasi. Berdasarkan hasil observasi dan penyebaran kuesioner yang penulis lakukan di SMA Negeri 2 Padang Cermin Kab. Pesawaran masih terdapat peserta didik kelas XI yang memiliki komunikasi interpersonal yang rendah seperti: berbicara pada saat ada yang sedang menyampaikan pesan, terbata- bata saat sedang menyampaikan pesan atau tujuan, sering menggunakan bahasa yang sulit dipahami sehingga mengakibatkan multitafsir, kemauan yang rendah untuk mengakui kesalahan dan cenderung menyalahkan orang lain, kurangnya rasa akrab, membantah perintah. Atas dasar hal tersebut peneliti mencoba menerapkan layanan bimbingan pribadi-sosial untuk meningkatkan komunikasi interpersonal peserta didik. Tujuan penelitian ini untuk mengetahui komunikasi interpersonal peserta didik dan untuk mengetahui apakah komunikasi interpersonal dapat ditingkatkan dengan menggunakan layanan bimbingan pribadi-sosial peserta didik kelas XI SMA Negeri 2 Padang Cermin Kb. Pesawaran. Metode yang digunakan dalam penelitian ini adalah penelitian pre-experimental dengan desain yang digunakan dalam penelitian ini one group pretestposttest design. Sampel dalam penelitian berjmlah 10 peserta didik kelas XI SMA Negeri 2 Padang Cermin Kab. Pesawaran tahun pelajaran 2016/2017 yang memiliki komunikasi interpersonal rendah. Teknik pengumpulan data dalam penelitian ini menggunakan observasi, metode kuisioner, wawancara, dan dokumentasi tehnik pendukung. Hasil analisis data menunjukan bahwa terdapat peningkatan terhadap komunikasi interpersonal peserta didik di sekolah sebelum diberikan layanan konseling kelompok dan sesudah diberikan layanan. Hal ini ditunjukan dari pengujian hipotesis dengan menggunakan uji t (t-test), dari hasil pretest dan posttest yang diperoleh dalam kelompok eksperimen $\mathrm{t}$ hitung $=50.250>\mathrm{t}$ tabel $0.05=$ 2.262, $\mathrm{df}=\mathrm{n}-1=10-1=9$ dengan $\mathrm{p}$ value $<\mathrm{t}$ tabel $(0.000<0.005)$, maka Ho ditolak dan Ha diterima yang bermakna layanan bimbingan pribadi-sosial dapat meningkatkan komunikasi interpersonal peserta didik. Saran yang diajukan peneliti yaitu kepada guru bimbingan perlu menindak lanjuti jika terdapat peserta didik yang mengalami hambatan atau kesulitan dalam bekomunikasi di lingkungannya. Karena hal ini dapat mempengaruhi peserta didik dalam proses berinteraksi serta belajar mengajar, dengan dapat menerapkan layanan konseling kelompok bimbingan pribadi-sosial.
\end{abstract}

Kata Kunci: layanan bimbingan pribadi-sosial, komunikasi interpersonal

\section{Pendahuluan}

Beberapa faktor yang mempengaruhi keterampilan komunikasi pada peserta didik yaitu faktor internal dan faktor eksternal. Faktor internal merupakan yang berasal dari dalam individu, meliputi intelegensi, kepribadian serta kondisi fisik dan lain-lain. Sedangkan faktor eksternal merupakan faktor yang berasal dari luar individu, meliputi pola asuh orang tua, lingkungan sekolah, maupun masyarakat.

Dampak yang sering muncul dalam kegiatan komunikasi interpersonal antara lain adalah rendahnya keterbukaan peserta didik terhadap guru mengenai permasalahan yang sedang dihadapinya. Keengganan melakukan interaksi komunikasi dalam kegiatan pembelajaran, muncul sifat minder dan seringnya terjadi konflik antar anggota sekolah yang dalam hal ini merupakan suatu ciri bahwa lingkungan sosial tersebut mengalami tingkat efektivitas komunikasi interpersonal yang rendah.

Suranto dalam skripsi Muhamad Ahdiyat berpendapat bahwa efektifitas komunikasi interpersonal bersifat positif apabila mengarah kepada suatu kerjasama dan bersifat negatif apabila mengarah kepada suatu pertentangan. Mengarah pada suatu kerjasama maksudnya 
dapat saling mempengaruhi saat berkomunikasi dan menimbulkan optimalisasi potensi akademik, sosial dan pribadi. Dan mengarah kesuatu pertentangan maksudnya adalah yang berdampak pada kurang optimalnya potensi akademik, sosial dan pribadinya.

Ciri-ciri komunikasi interpersonal yang bersifat positif ditandai dengan sikap: (1) Respek; (2) Empati; (3) Humble; (4) Meningkatkan hubungan interpersonal; (5) Clarity; (6) Audible; dan (7) Dapat menyampaikan pesan secara sukarela. Sedangkan ciri-ciri komunikasi interpersonal yang negatif atau mengarah suatu pertentangan adalah kebalikan dari yang efektif, yaitu ditandai dengan sikap: (1) Respek rendah; (2) Empati rendah; (3) Humble rendah; (4) Hubungan Interpersonal rendah; (5) Clarity rendah; (6) Audible rendah; dan (7) Menyampaikan pesan sukarela rendah.

Menyoroti bentuk tentang fenomena yang banyak dijumpai di sekolah-sekolah saat ini adalah masih banyak peserta didik yang memilki ciri komunikasi interpersonal sebagaimana yang terjadi di sekolah SMA Negeri 2 Padang Cermin Kab. Pesawaran. Hal ini dapat diketahui melalui perilaku mereka dalam berinteraksi atau berhubungan sosial dengan teman sebayanya maupun seluruh warga di sekolah. Karena pada dasarnya peserta didik ditekankan untuk dapat bersosialisasi dan memiliki kecakapan dalam berkomunikasi interpersonal yang baik untuk dapat menyesuaikan diri dengan baik dan meningkatkan kualitas dalam belajarnya. Komunikasi interpersonal yang terjalin dengan baik dapat menciptakan hubungan yang hangat dan nyaman dalam kehidupan kesehariannya.

A. Bimbingan Pribadi-Sosial

Secara harfiah, istilah bimbingan berasal dari bahasa Inggris yaitu "guidence". Guidence dapat diartikan sebagai bimbingan, bantuan, pimpinan, arahan, pedoman, petunjuk. Guidence sendiri berasal dari kata "(to) guide" yang berarti menuntun, mempedomani, menjadi petunjuk jalan, mengemudikan. Adapun pembahasan dalam buku ini kata guidance dipergunakan untuk pengertian bimbingan atau bantuan.

Secara umum bimbingan dapat diartikan sebagai suatu proses pemberian bantuan kepada individu atau kelompok yang dilakukan secara berkesinambungan supaya individu atau kelompok tersebut dapat memahami dirinya sendiri, sehingga dia sanggup mengarahkan dirinya dan dapat bertindak secara wajar, sesuai dengan tuntutan dan keadaan lingkungan sekolah, keluarga, masyarakat dan kehidupannya. Menurut para ahli, pengertian konseling adalah sebagai berikut:

Menurut Prayitno konseling adalah proses pemberian bantuan yang dilakukan melalui wawancara konseling oleh seorang ahli kepada individu yang sedang mengalami sesuatu masalah yang bermuara pada teratasinya masalah yang dihadapi oleh klien. Sedangkan Menurut Rifda El Fiah konseling merupakan proses pemberian bantuan yang dilakukan melalui wawancara, konseling oleh seorang konselor kepada individu yang sedang mengalami sesuatu masalah dengan tujuan agar klien dapat mencapai pemahaman yang lebih baik terhadap dirinya dan dapat mengatasi masalah yang dihadapinya.

Dari pendapat para ahli di atas bahwa bimbingan adalah suatu proses bantuan yang diberikan kepada individu atau sekelompok individu utnuk memecahkan kesulitan-kesulitan agar mereka dapat mengembangkan kemampuan dirinya sendiri dan menjadi pribadi yang mandiri, yang mencakup pokok mengenal diri sendiri dan lingkungannya. Sedangkan konseling adalah suatu proses bantuan yang diberikan kepada individu dengan tatap muka melalui wawancara untuk memecahkan suatu permasalahan yang dihadapi individu oleh seorang pekerja yang profesional atau terlatih.

Secara keseluruhan dapat disimpulkan bahwa bimbingan dan konseling adalah suatu proses pemberian bantuan oleh konselor kepada klien dalam memecahkan suatu permasalahan yang dihadapi agar klien dapat mandiri, mengembangkan kemampuan dirinya sendiri maupun lingkunganya. Dalam bimbingan dan konseling terdapat empat bidang 
diantaranya bidang pribadi, bidang sosial, bidang belajar, bidang karir, dan bidang pribadisosial. Maka dalam penelitian ini terfokus pada bidang layanan bimbingan pribadi-sosial.

Bimbingan peribadi (personal guidance) merupakan bimbingan yang diarahkan kepada individu yang bertujuan untuk memenuhi kebutuhan individu, hingga yang bersangkutan memiliki sasaran yang objektif yang cukup di dalam kehidupan individunya. Sedangkan bimbingan sosial (social guidance) yaitu bimbingan yang diarahkan kepada individu yang bertujuan untuk memenuhi kebutuhan hingga individu yang bersangkutan dapat memenuhi fungsinya sebagai makhluk hidup sosial yang baik.

Dapat disimpulkan bahwa bimbingan pribadi-sosial yaitu suatu bimbingan yang diarahkan kepada individu/sekelompok orang untuk dapat membantu dan mengatasi permasalahan peserta didik yang terkait dalam aspek kehidupan pribadi individu baik dalam segi mental seseorang dan dalam kehidupan sosial baik dalam segi pegaulan, sikap toleransi, serta kerjasama yang bertujuan untuk melengkapi individu hingga memiliki sarana yang cukup bagi individu dalam melaksanakan fungsi sosialnya.

Adapun pengertian bimbingan pribadi-sosial menurut beberapa ahli adalah sebagai berikut:

Menurut Samsu Yusuf bimbingan pribadi-sosial adalah sebagai suatu upaya membantu individu dalam memecahkan masalah yang berhubungan dengan keadaan psikologis dan sosial klien sehingga individu memantapkan kepribadian dan mengembangkan kemampuan individu dalam menangani masalah-masalah dirinya. Diperkuat dengan pendapat Ahmad Juntika yang dimaksud dengan bimbingan pribadi-sosial adalah untuk membantu para individu dalam menyelesaikan masalah-masalah pribadi-sosial. misalnya pergaulan, penyelesaian konflik dan penyesuaian diri.

Mengacu pada pendapat para ahli di atas dapat dinyatakan bahwa bimbingan pribadisosial merupakan usaha bimbingan dalam membantu menghadapi dan menyelesaikan masalah-masalah yang dialami peserta didik baik pribadi maupun sosial dan mengembangkan sistem pemahaman diri dan sikap-sikap yang positif.

Syamsu Yusuf, secara rinci menyebutkan tujuan yang ingin dicapai dari layanan bimbingan pribadi-sosial adalah sebagai berikut:

a. memiliki komitmen yang kuat dalam mengamalkan nilai-nilai keimanan dan ketaqwaan kepada tuhan yang maha esa, baik dalam kehidupan pribadi, keluarga, pergaulan dengan teman sebaya, sekolah, tempat kerja maupun masyarakat pada umumnya;

b. memiliki sifat toleransi terhadap umat beragama lain dengan saling menghormati dan memelihara hak dan kewajibannya masing-masing;

c. memiliki pemahaman tentang irama kehidupan yang bersifat fluktuatif antara yang menyenangkan dan tidak menyenangkan serta mampu meresponnya secara positif sesuai dengan ajaran agama yang dianutnya;

d. memiliki pemahaman dan penerimaan diri secara objektif dan konstruktif, baik yang terkait dengan keunggulan maupun kelemahan baik fisik maupun psikis; memiliki sifat positif atau respek terhadap diri sendiri dan orang lain;

e. memiliki kemampuan untuk melakukan pilihan secara sehat;

f. bersikap respek terhadap orang lain, menghormati atau menghargai orang lain, tidak melecehkan martabat dan harga dirinya;

g. memiliki rasa tanggung jawab yang diwujudkan dalam bentuk komitmen terhadap tugas atau kewajibannya;

h. memiliki kemampuan berinteraksi sosial (human relationship) yang diwujudkan dalam bentuk hubungan persahabatan, persaudaraan, atau silaturrahim dengan sesama manusia; 
i. memiliki kemampuan dalam menyelesaikan konflik (masalah) baik bersifat internal maupun dengan orang lain; dan

j. memiliki kemampuan untuk mengambil keputusan secara efektif.

Berdasarkan pemaparan di atas, diketahui bahwa tujuan dari layanan bimbingan pribadi-sosial adalah membantu peserta didik untuk dapat mengamalkan nilai-nilai keimanan dan ketaqwaan terhadap Tuhan Yang Maha Esa, mampu memahami dan menerima kelebihan dan kekurangan diri sendiri, bersikap respek terhadap sesama dan diri sendiri, mengambil keputusan secara efektif, memiliki rasa tanggung jawab, memiliki kemampuan berinteraksi sosial dan dapat menyelesaikan konflik pribadi maupun sosial.

Adapun tugas-tugas perkembangan pribadi-sosial yang ingin dicapai melalui proses bantuan bimbingan dan konseling antara lain:

a. memiliki kesadaran diri;

b. dapat mengembangkan sikap positif;

c. membuat pilihan secara sehat;

d. mampu menghargai orang lain;

e. memiliki rasa tanggung jawab;

f. mengembangkan ketrampilan hubungan antar pribadi;

g. dapat menyelesaikan konflik; dan

h. dapat membuat keputusan secara efektif.

Inti dari pendapat ahli akan tujuan yang ingin dicapai dari bimbingan pribadi-sosial adalah membantu individu atau peserta didik agar mampu menerima dan memahami dirinya sendiri serta lingkungan sekitarnya, sehingga peserta didik dapat menyelesaikan permasalahan pribadi dan sosial yang dihadapi.

Berkaitan dengan pribadi dan sosial, hendaknya seorang konselor mengusahakan beberapa hal berikut demi pendampingan kepada para peserta didiknya:

a. mengenal diri, keluarga, teman dan orang lain;

b. masalah pergaulan, hubungan dengan keluarga dan teman;

c. menyelesaikan konflik dengan orang tua, teman, dan diri;

d. penyesuaian diri dengan lingkungan;

e. masalah perkembangan diri, intelektual, sosial, emosional, dan spritual;

f. memotivasi diri, mengendalikan diri, menghargai orang lain, percaya diri;

g. nilai-nilai hidup kebenaran, keadilan, kejujuran, kesetiaan, cinta kasih, tanggung jawab, kedisiplinan, ketekunan, kebersihan; dan mengatasi rasa malu, rasa minder, dan rasa takut berleihan

Adapun fungsi bimbingan pribadi-sosial sebagai berikut.

a. berubah menuju pertumbuhan. pada bimbingan pribadi-sosial, konselor secara berkesinambungan memfasilitasi individu agar mampu menjadi agen perubahan (agent of change) bagi dirinya dan lingkungannya. konselor juga berusaha membantu individu sedemikian rupa sehingga individu mampu menggunakan segala sumber daya yang dimilikinya untuk berubah;

b. pemahaman diri secara penuh dan utuh. individu memahami kelemahan dan kekuatan yang ada dalam dirinya, serta kesempatan dan tantangan yang ada diluar dirinya. pada dasarnya melalui bimbingan pribadi sosial diharapkan individu mampu mencapai tingkat kedewasaan dan kepribadian yang utuh dan penuh seperti yang diharapkan, sehingga individu tidak memiliki kepribadian yang terpecah lagi dan mampu mengintegrasi diri dalam segala aspek kehidupan secara utuh, selaras, serasi dan seimbang; 
c. belajar berkomunikasi yang lebih sehat. bimbingan pribadi sosial dapat berfungsi sebagai media pelatihan bagi individu untuk berkomunikasi secara lebih sehat dengan lingkungannya;

d. berlatih tingkah laku baru yang lebih sehat. bimbingan pribadi-sosial digunakan sebagai media untuk menciptakan dan berlatih perilaku baru yang lebih sehat;

e. belajar untuk mengungkapkan diri secara penuh dan utuh. Melalui bimbingan pribadisosial diharapkan individu dapat dengan spontan, kreatif, dan efektif dalam mengungkapkan perasaan, keinginan, dan inspirasinya; dan

f. individu mampu bertahan. melalui bimbingan pribadi-sosial diharapkan individu dapat bertahan dengan keadaan masa kini, dapat menerima keadaan dengan lapang dada, dan mengatur kembali kehidupannya dengan kondisi yang baru.

Dari penjelasan di atas bahwa fungsi bimbingan pribadi-sosial adalah agar individu mampu memahami, menerima kelebihan dan kekurangan dalam dirinya, serta mampu mengadakan perubahan- perubahan positif pada diri individu itu sendiri dan dapat menyelesaikan permasalahannya secara baik.

Pada hakekatnya kompetensi pribadi-sosial banyak dirumuskan secara berbeda, intrapersonal dan interpersonal, self-knowledge, interpersonal skill, dan atau personal and social skills. Ketiga rumusan tersebut pada hakekatnya memiliki maksud dan pengertian yang relatif sama, yaitu menggambarkan antara kompetensi pribadi-sosial yang terkait dengan orang lain atau lingkungannya yang didasari dengan adanya komitmen transcendetal, yaitu dengan penciptanya.

Kedua relasi intra dan inter pribadi-sosial merupakan suatu kesatuan yang secara fungsional sulit dipisahkan, sehingga kedua kecakapan dipandang lebih fungsional dan bermakna, manakala disatukan.

\section{B. Komunikasi Interpersonal}

Komunikasi adalah bentuk tingkah laku seseorang baik verbal maupun non- verbal yang ditanggapi oleh orang lain. Setiap bentuk tingkah laku yang mengungkapkan pesan tertentu merupakan bentuk komunikasi. Dalam kegiatan komunikasi menekankan pentingnya komunikasi sebagai subjek komunikasi bukan sebagai objek komunikasi.

Istilah komunikasi secara etimologis berasal dari bahasa latin Communikatus atau Comunicare yang berarti memberitahukan atau berpartisipasi. Sedangkan Sutoyo mengemukakan bahwa dari segi istilah komunikasi yang dalam bahasa inggrisnya Communication berasal dari kata Communication yang bersumber pada kata Communis yang berarti sama (sama makna).

Harold J. Hovland dalam Slamet Santoso mengatakan komunikasi adalah proses dimana seorang individu menyampaikan rangsangan untuk mengubah tingkah laku individu lain. Menurut sutoyo bahwa seseorang dikatakan sedang berkomunikasi dengan orang lain apabila keduanya selain bahasa yang digunakan juga mengerti makna dari bahan yang dijadikan topik dalam komunikasi. Sebab mengerti bahasa belum cukup, yang tak kalah penting mengerti makna yang terkandung dalam bahasa itu agar terjadi komunikasi yang berlangsung baik dan komunikatif. Jadi dalam komunikasi minimal harus mengandung kesamaan makna antara dua pihak yang terlibat komunikasi.

Dari pandangan tersebut maka dapat diperoleh kesimpulan bahwa komunikasi interpersonal merupakan proses interaksi kegiatan manusia yang terdiri dari dua orang atau lebih yang saling mempengaruhi dan membentuk informasi, pengetahuan, pikiran agar dapat mengunggah partisipasi satu sama lain, sehingga informasi yang diberitahukan tersebut menjadi milik bersama. Untuk dapat menjadikan proses komunikasi interpersonal berhasil dengan baik sesuai dengan yang diharapkan, diantaranya ialah harus saling memahami lawan 
bicara, mampu mengomunikasikan pikiran secara tepat dan jelas, kemampuan saling menerima dan saling memberi dukungan atau saling tolong menolong satu sama lain, serta mampu memecahkan konflik dan bentuk-bentuk masalah interpersonal yang mungkin muncul

Berkomunikasi merupakan keharusan bagi manusia, karena dengan komunikasi kebutuhan manusia akan terpenuhi. Menurut Johson dalam mengemukakan beberapa peranan yang disumbangkan oleh komunikasi interpersonal dalam rangka menciptakan kebahagiaan hidup manusia, adalah sebagai berikut: (a) komunikasi interpersonal mambantu perkembangan itelektual dan sosial kita; (b) identitas atau jati diri kita terbentuk dalam dan lewat komunikasi dengan orang lain; (c) dalam rangka memahami realitas disekeliling kita serta menguji kebenaran kesan-kesan dan pengertian yang kita miliki tentang dunia disekitar kita, kita perlu membandingkannya dengan kesan-kesan dan pengertian orang lain dan realitas yang sama; (d) kesehatan mental kita sebagian besar juga ditentukan oleh kualitaskomunikasi atau hubungan kita dengan orang lain, lebih-lebih orang yang merupakan tokoh signifikan (significant figures) dalam hidup kita.

Agar mampu memulai mengembangkan dan memelihara komunikasi yang akrab, hangat dan produktif dengan orang lain, kita perlu memiliki sejumlah keterampilan dasar komunikasi. Menurut Johnson beberap ketemapilan dasar yang dimaksud adalah sebagai berikut:

a. kita harus mampu saling memahami. agar dapat saling memahami perta harus saling percaya, lalu saling membuka diri. membuka diri kepeda orang lain dan mendengarkan dengan penuh perhatian ketika orang lain sedang membuka diri kepada kita adalah cara yang jitu untuk memulai dan memelihara komunikasi.

b. kita harus mampu mengkomunikasikan pikiran dan perasaan kita secara jelas. dengan menunjukan sikap hangat dan rasa senangserta menunjukan bahwa kita memahami lawan komunikasi kita.

c. kita harus saling menerima dan saling memberikan dukungan atau saling menolong.

d. harus mampu memecahkan konflik dan bentuk masalah interpersonal lain yang mungkin muncul dalam komunikasi kita dengan orang lain, melalui cara- cara yang konstruktif.

Efektifitas komunikasi interpersonal jika dijelaskan dari prespektif the inevitable of laws of effective communication atau lima hukum komunikasi efektif meliputi lima aspek yang disingkat REACH yaitu respect, empathy, audible, clarity, dan humble. Hal ini relevan dengan prinsip komunikasi interpersonal yakni sebagai upaya meraih perhatian, pengakuan, cinta kasih, maupun penghargaan terhadapa diri dari lingkungan sosial.

1) Respect adalah suatu sikap menghargai setiap individu yang menjadi sasaran pesan yang kita sampaikan. Rasa hormat dan saling menghargai adalah kunci dari prilaku ini, dimana pada prinsipnya setiap diri manusia ingin dihargai dan dihormati. Komunikasi interersperonal yang baik ditandai dengan munculnya respect dalam komunikasi, yang menyebabkan kegiatan komunikasi menjadi nyaman dan antara komunikator dan komunikan seakan- akan tidak terdapat jarak antara keduanya.

2) Empathy adalah "kemampuan menempatkan diri kita pada situasi atau kondisi yang dihadapi orang lain". Rasa simpati ini muncul sebagai salah satu indikator dalam komunikasi interpersonal yang baik. Rasa empati akan membantu kita untuk menyampaikan pesan dengan cara sikap mudah diterima oleh komunikan. Sehingga merasa dihargai dan diterima sebagai individu bukan sebagai objek.

3) Audible memiliki makna dimengerti atau dimengerti dengan baik. Komunikasi interpersonal yang baik adalah komunikasi yang dapat didengarkan dan dipahami maksud dan tujuan dari penyampaian pesan komunikator kepada komunikan, tanpa meninggalkan sisi humanis dari komunikan. Artinya bahwa dalam komunikasi ini 
sangat penting ketika menyampaikan suatu pesan tidak hanya dapat didengarkan dan dipahami oleh komunikan, akan tetapi juga harus diperhatikan cara penyampaian pesan yang meliputi pemilihan kata, intonasi dan kenyaringan suara, sehingga pesan dapat ditangkap dengan sempurna oleh komunikan.

4) Clarity dapat diartikan sebagai kejelasan dari suatu pesan. Yang artinya bahwa pesan yang disampaikan harus jelas dan tidak menimbulkan multi interprestasi atau berbagai tafsir yang berlainan. Komunikasi interpersonal yang baik adalah komunikasi yang menimbulkan kejelasan maksud dan tujuan penyampaian pesan dengan memperhatikan aspek psikologis komunikan. Clarity dapat pula diartikan sebagai keterbukaan, yang mana komunikasi interpersonal yang baik memiliki tingkat keterbukaan yang tinggi, terdapat keakraban dan tidak ada jarak antara komunikator dan komunikan.

5) Humble dalam bahasa indonesia dartikan sebagai sikap rendah hati. Sikap rendah hati pada intinya antara lain: sikap melayani, sikap menghargai, mau mendengar dan menerima kritik, tidak sombong dan memandang rendah orang lain, berani mengakui kesalahan, rela memaafkakan, lemah lembut, dan penuh pengendalian diri, serta menggunakan kepentingan yang lebih besar.

\section{Metode Penelitian}

Dalam sebuah proses penelitian seseorang akan menggunakan satu atau beberapa metode yang dipilih akan disesuaikan dengan sifat dan karakteristik penelitian yang digunakan. Jenis penelitian yang peneliti gunakan dalam penelitian ini adalah metode kuantitatif eksperimen.

\section{Hasil dan Pembahasan}

Sebelum dilakukan uji t atau t-test terlebih dahulu dilakukan uji normalitas terhadap data yang akan dicari hasilnya. Uji normalitas ini bertujuan untuk menormalkan semua data, apakah layak untuk dilakukan uji selanjutnya. Hasil uji normalitas dapata dilihat pada table 4.13 sebagai berikut:

\section{Tabel 4.13 Hasil Uji Normalitas}

\begin{tabular}{|l|l|r|}
\hline \multicolumn{2}{|c|}{ One-Sample Kolmogorov-Smirnov Test } \\
\hline \multicolumn{2}{|l|}{} & \multicolumn{1}{|c|}{ Total } \\
\hline $\mathrm{N}$ & 34 \\
\hline $\begin{array}{l}\text { Normal } \\
\text { Parameters }\end{array}$ & Mean & 194.18 \\
\cline { 2 - 3 } & Std. Deviation & 51.108 \\
\hline $\begin{array}{l}\text { Most } \\
\text { Extreme } \\
\text { Differences }\end{array}$ & Absolute & .158 \\
\cline { 2 - 3 } & Positive & .103 \\
\cline { 2 - 3 } & Negative & .158 \\
\hline Kolmogorov-Smirnov Z & .921 \\
\hline Asymp. Sig. (2-tailed) & .365 \\
\hline $\begin{array}{l}\text { a. Test distribution is } \\
\text { Normal. }\end{array}$ & \\
\hline
\end{tabular}

Berdasarkan tabel 4.13 diatas dapat kita ketahui bahwa data yang disajikan memenuhi asumsi normalitas. Hal tersebut dilihat dari kolom kolmogorov-smirnov $\mathrm{Z}$ nilainya 0.921 dan nilai Asymp.sig.(2-tiled) 0.365, maka nilai tersebut diatas 0.05. Dapat dilihat dengan jelas bahwa data sudah bisa dikatakan normal. 
Pengaruh layanan bimbingan pribadi-sosial dalam meningkatkan komunikasi interpersonal peserta didik dapat dilihat dari perbandingan sebelum diberikan perlakuan (pretest) dan sesudah diberi perlakuan (posttest). Maka terlebih dahulu dilakukan uji-t untuk mengetahui pengaruh layanan bimbingan pribadi- sosial dalam meningkatkan komunikasi interpersonal peserta didik. Serta untuk membuktikan hipotesis Ha atau Ho yang diperoleh dalam penelitian ini, maka penelitian menggunakan rumus t-test dengan DF (degree of freedom $)=\mathrm{N}-1$ atau 10-1 =9. Dan dikonsultasikan taraf signifikan atau level of significane 0,005 . Hipotesis yang diajukan yang dilakukan dalam penelitian ini adalah:

$\mathrm{Ha}=$ Keterampilan komunikasi interpersonal peserta didik dikelas XI SMA Negeri 2 Padang Cermin Kab. Pesawaran tahun ajaran 2016/2017 dapat ditingkatkan melalui layanan bimbingan pribadi-sosial.

Ho $=$ Keterampilan komunikasi interpersonal peserta didik di kelas XI SMA Negeri 2 Padang Cermin Kab. Pesawaran tahun ajaran 2016/2017 tidak dapat ditingkatkan melalui layanan bimbingan pribadi-sosial.

Penguji hasil hipotesis dengan menggunakan uji t-test (paired sample test) atau uji $\mathrm{T}$ untuk sampel berpasangan dengan menggunakan program SPSS for window reliase 16, dapat dilihat dari hasil tabe 14.14 sebagai berikut:

\begin{tabular}{|c|c|c|c|c|c|c|c|c|c|}
\hline & \multicolumn{5}{|c|}{ Paired Differences } & \multirow{3}{*}{$\mathrm{t}$} & \multirow{3}{*}{$\mathrm{df}$} & \multirow{3}{*}{$\begin{array}{l}\text { Sig. (2- } \\
\text { tailed) }\end{array}$} \\
\hline & & \multirow[t]{2}{*}{ Mean } & \multirow[t]{2}{*}{$\begin{array}{c}\text { Std. } \\
\text { Deviation }\end{array}$} & \multirow[t]{2}{*}{$\begin{array}{c}\text { Std. Error } \\
\text { Mean }\end{array}$} & \multicolumn{2}{|c|}{$\begin{array}{c}95 \% \text { Confidence } \\
\text { Interval of the } \\
\text { Difference }\end{array}$} & & & \\
\hline & & & & & Lower & Upper & & & \\
\hline $\begin{array}{c}\text { Pair } \\
1\end{array}$ & $\begin{array}{l}\text { PRETEST - } \\
\text { POSTEST }\end{array}$ & 53.600 & 3.373 & 1.067 & 56.013 & 51.187 & 50.250 & 9 & .000 \\
\hline
\end{tabular}

Dari tabel 4.14 dapat diketahui bahwa keseluruhan komunikasi interpersonal peserta didik terdapat peningkatan yaitu dapat dilihat dari rata- rata kedua variabel sebelum dan sesudah diberikan treatment adalah 53.600 dan berdasarkan hasil pengujian t hitung $=50.250$ pada derajat kebebasan (df) 9, kemudian dibandingkan dengan t tabel $0.05=2.262$ dengan ketentuan harga $t$ hitung lebih besar dari t tabel $(50.250 \geq 2.262)$, maka Ho "keterampilan komunikasi interpersonal peserta didik kelas XI SMA Negeri 2 Padang Cermin Kab. Pesawaran tahun ajaran 2016/2017 tidak dapat ditingkat melalui layanan bimbingan pribadisosial" ditolak dan Ha "keterampilan komunikasi interpersonal peserta didik kelas XI SMA Negeri 2 Padang Cermin Kab. Pesawaran tahun ajaran 2016/2017 dapat ditingkat melalui layanan bimbingan pribadi-sosial" diterima. Gambar 4.1 menunjukan rata-rata komunikasi interpersonal peserta didik sebelum dan sesudah diberikan layanan.

Gambar 4.1 Rata-rata Peningkatan Pretest dan Postest

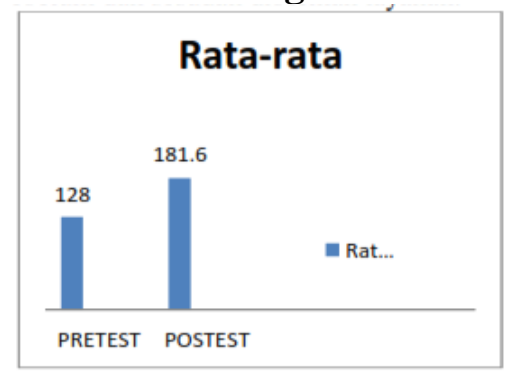

Dapat dilihat dari peningkatan berdasarkan indikator respek pada table 4.15 sebagai berikut:

\section{Tabel 4.15 Hasil T-test Indikator Respek}




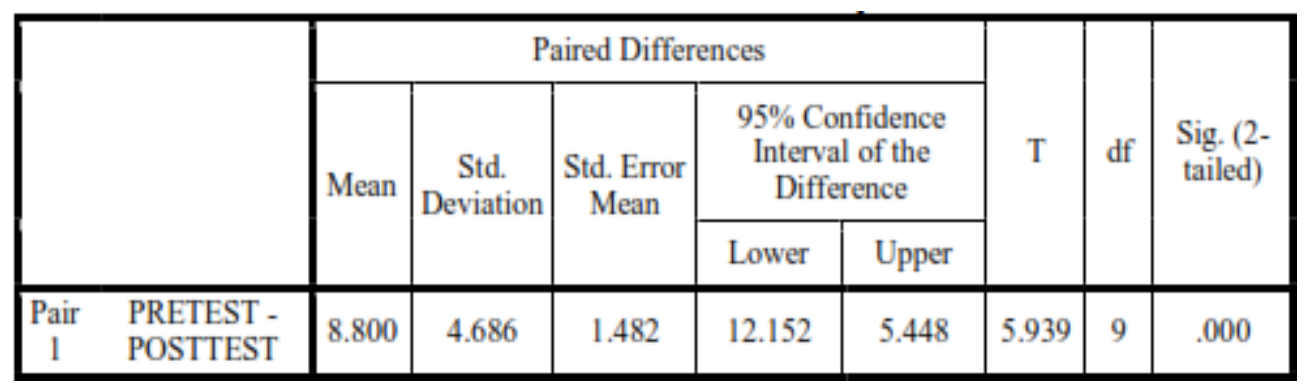

Dari tabel 4.15 dapat diketahui bahwa komunikasi interpersonal pada 30 indikator respek terdapat peningkatan yaitu dilihat dari rata-rata kedua variabel 25 (sebelum dan sesudah diberi perlakuan) adalah 8.800, dan berdasarkan hasil 20 pengujian t hitung $=5.939$, pada derajat kebebasan (df) 9, kemudian dibandingkan dengan t tabel 0,05 $=2.262$ dengan ketentuan harga t hitung lebih besar dari t tabel (5.939 $\geq 2.262$ ), maka Ho ditolak dan Ha diterima. Jadi keterampilan komunikasi interpersonal peserta didik SMA Negeri 2 Padang Cermin Kab. Pesawaran tahun ajaran 2016/2017 dapat ditingkatkan melalui layanan bimbingan pribadi-sosial.Rata-rata peningkatan hasil T-test indikator respek pada gambar grafik 4.2 sebagai berikut:

\section{Gambar 4.2 Rata-Rata Hasil T-test Indikator Respek}



a) Hasil T-test Indikator Empati

Dapat dilihat dari peningkatan berdasarkan indikator empati pada table 4.16 sebagai berikut:

Tabel 4.16 Hasil T-test Indikator Sikap Empati

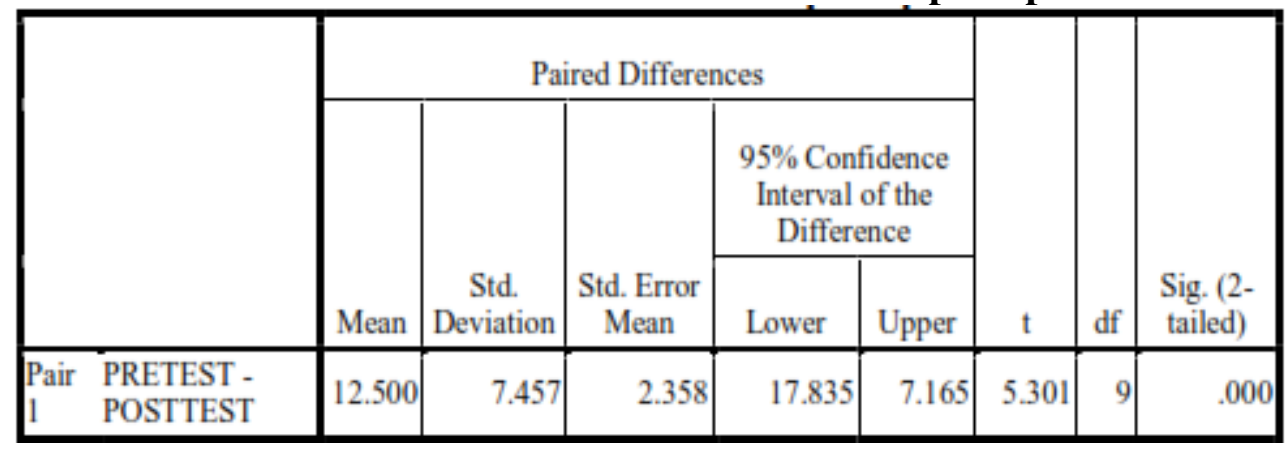

Dari tabel 4.16 dapat diketahui bahwa komunikasi interpersonal pada indikator empati terdapat peningkatan yaitu dilihat dari rata-rata kedua variabel (sebelum dan sesudah diberi perlakuan) adalah 12.500 , dan berdasarkan hasil pengujian $t$ hitung $=5.301$, pada derajat kebebasan (df) 9, kemudian dibandingkan dengan t tabel $0,05=2.262$ dengan ketentuan harga $t$ hitung lebih besar dari $t$ tabel $(5.301 \geq 2.262)$, maka Ho ditolak dan Ha diterima. Jadi keterampilan komunikasi interpersonal peserta didik SMA Negeri 2 Padang Cermin Kab. 
Pesawaran tahun ajaran 2016/2017 dapat ditingkatkan melalui layanan bimbingan pribadisosial.Rata-rata peningkatan hasil T-test indikator empati pada gambar grafik 4.3, sebagai berikut:

\section{Gambar 4.3 Rata-rata Hasil T-test Indikator Empati}

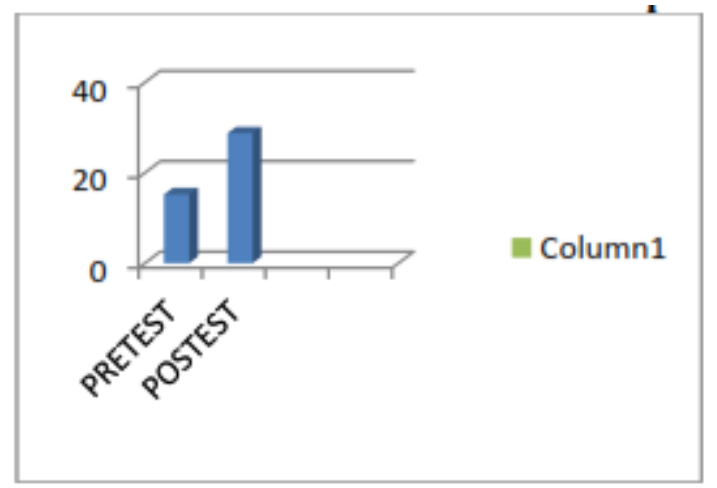

b) Hasil T-test Indikator Humble

Dapat dilihat dari peningkatan berdasarkan indikator respek pada tabel 4.17 sebagai berikut:

Tabel 4.17 Hasil Indikator Humble

\begin{tabular}{|c|c|c|c|c|c|c|c|c|}
\hline & \multicolumn{5}{|c|}{ Paired Differences } & \multirow[b]{3}{*}{$\mathrm{t}$} & \multirow[b]{3}{*}{ df } & \multirow{3}{*}{$\begin{array}{l}\text { Sig. (2- } \\
\text { tailed) }\end{array}$} \\
\hline & \multirow[b]{2}{*}{ Mean } & \multirow{2}{*}{$\begin{array}{c}\text { Std. } \\
\text { Deviation }\end{array}$} & \multirow{2}{*}{$\begin{array}{c}\text { Std. Error } \\
\text { Mean }\end{array}$} & \multicolumn{2}{|c|}{$\begin{array}{l}95 \% \text { Confidence } \\
\text { Interval of the } \\
\text { Difference }\end{array}$} & & & \\
\hline & & & & Lower & Upper & & & \\
\hline $\begin{array}{ll}\text { Pair } & \text { PRETEST - } \\
1 & \text { POSTTEST }\end{array}$ & 10.100 & 5.744 & 1.816 & 14.209 & 5.991 & 5.561 & 9 & .000 \\
\hline
\end{tabular}

Dari tabel 4.17 dapat diketahui bahwa komunikasi interpersonal pada indikator empati terdapat peningkatan yaitu dilihat dari rata-rata kedua variabel (sebelum dan sesudah diberi perlakuan) adalah 10.100 , dan berdasarkan hasil pengujian t hitung $=5.561$, pada derajat kebebasan (df) 9, kemudian dibandingkan dengan t tabel $0,05=2.262$ dengan ketentuan harga $t$ hitung lebih besar dari t tabel $(5.561 \geq 2.262)$, maka Ho ditolak dan Ha diterima. Jadi keterampilan komunikasi interpersonal peserta didik SMA Negeri 2 Padang Cermin Kab. Pesawaran tahun ajaran 2016/2017 dapat ditingkatkan melalui layanan bimbingan pribadisosial.Rata-rata peningkatan hasil T-test indikator humble pada gambar grafik 4.4, sebagai berikut:

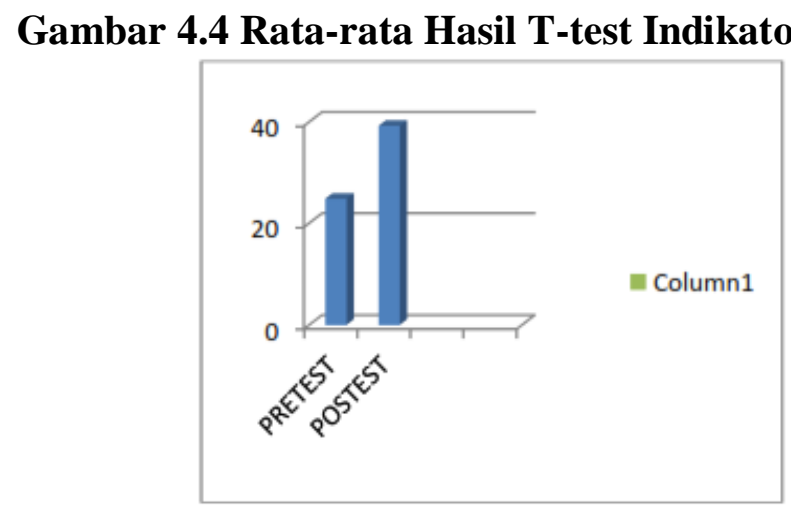

c) Hasil T-test Indikator Hubungan Interpersonal 
Dapat dilihat dari peningkatan berdasarkan indikator Hubungan Interpersonal pada tabel 4.18 sebagai berikut:

Tabel 4.18 Hasil Indikator Hubungan Interpersonal

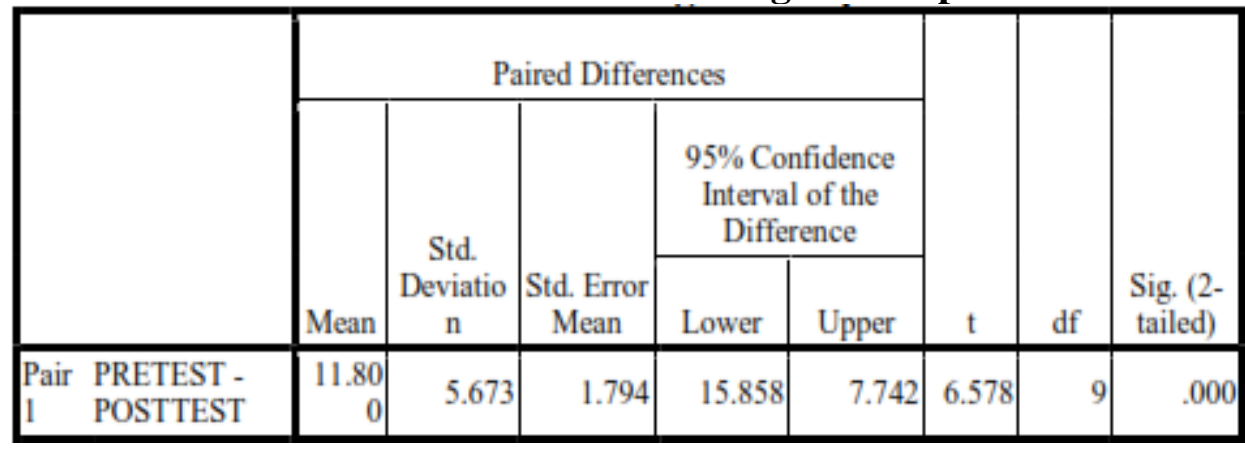

Dari tabel 4.18 dapat diketahui bahwa komunikasi interpersonal pada indikator hubungan interpersonal terdapat peningkatan yaitu dilihat dari rata-rata kedua variabel (sebelum dan sesudah diberi perlakuan) adalah11.800, dan berdasarkan hasil pengujian $\mathrm{t}$ hitung $=6.578$, pada derajat kebebasan (df) 9, kemudian dibandingkan dengan t table 0,05 = 2.262 dengan ketentuan harga t hitung lebih besar dari t tabel $(6.578 \geq 2.262)$, maka Ho ditolak dan Ha diterima. Jadi keterampilan komunikasi interpersonal peserta didik SMA Negeri 2 Padang Cermin Kab. Pesawaran tahun ajaran 2016/2017 dapat ditingkatkan melalui layanan bimbingan pribadi- sosial.Rata-rata peningkatan hasil T-test indikator hubungan interpersonal pada gambar grafik 4.5, sebagai berikut

\section{Gambar 4.5 Rata-rata Hasil Peningkatan Indikator Hubungan Interpersonal}

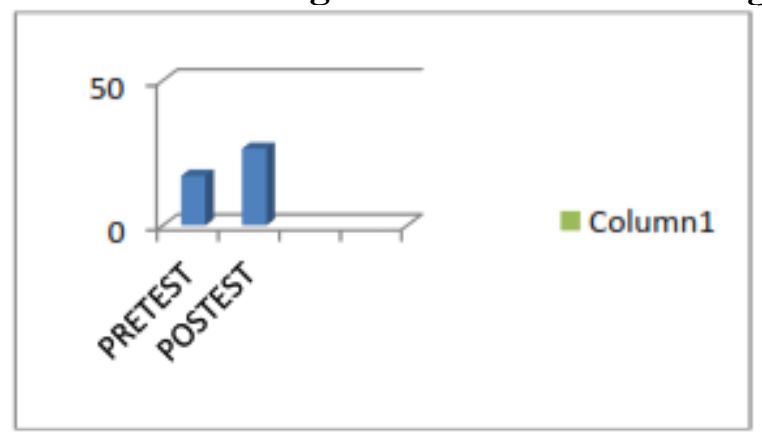

d) Hasil T-test Indikator Menyampaikan Pesan Secara Sukarela

Berdasarakan hasil penelitian diketahui bahwa terdapat peningkatan komunikasi interpersonal setelah diberikan layanan bimbingan pribadi-sosial. Dari 34 peserta didik yang ada di kelas XI terdapat 10 peserta didik yang mengalami komunikasi interpersonal rendah dan sangat rendah. Hal ini ditandai dengan sekor pretest yang termasuk kategori rendah dan sangat rendah.

Dari ketuju kriteria dalam komunikasi interpersonal yang dijadikan tolok ukur efektivitas komunikasi interpersonal, kebanyakan peserta didik yang menjadi anggota kelompok mengalami masalah dalam respek, yaitu penghargaan terhadap lawan bicara, sikap humble yaitu sikap rendah hati, yang ditandai dengan kemauan mengakui kesalahan dan rela memaafkan, hubungan antarpribadi, yang ditandai masih belum dirasakanya manfaat komunikasi interpersonal, serta clarity yang ditandai masih banyaknya pesan yang salah tafsir.

Kegiatan layanan bimbingan pribadi- sosial merupakan salah satu jenis layanan dalam bimbingan konseling yang bertujuan untuk menyelesaikan permasalahan dengan memanfaatkan dinamika kelompok. Penggunaan layanan bimbingan pribadi- sosial dengan memanfaatkan dinamika dalam konseling kelompok dianggap efektif untuk meningkatkan, 
karena dalam bimbingan pribadi-sosial setiap anggota diajak berlatih berkomunikasi, berempati dan menghargai lawan bicara, dan hal ini sangat membantu dalam upaya peningkatan komunikasi interpersonal peserta didik.

Kegiatan layanan bimbingan pribadi- sosial dengan tujuan meningkatkan komunikasi interpersonal peserta didik dilaksanakan selama 10 kali pertemuan dan diakhiri dengan posttest. Posttes dilakukan dengan tujuan untuk mengetahui adakah peningkatan komunikasi interpersonal dari anggota kelompok, sehingga dapat diketahui apakah layanan bimbingan pribadi-sosial dapat meningkatkan komunikasi interpersonal peserta didik.

Hasil posttest menunjukan terdapat peningkatan sekor dari pretest yang rendah menjadi meningkat sedang pada posttes. Hal ini menunjukan bahwa setelah peserta didik mengikuti layanan bimingan pribadi-sosial peserta didik mengalami peningkatan komunikasi interpersonalnya.

Selain itu dilakukan uji hipotesis menggunaka uji t-test dan diperoleh harga $\mathrm{t}$ hitung $=$ 50.250 kemudian dibandingkan dengan $\mathrm{t}$ table $0.05=2.262$ dengan ketentuan harga $t$ hitung lebih besar dari t tabel $(50.250 \geq 2.262)$, maka Ha diterima. Hal ini berarti perbedaan yang signifikan antara skor komunikasi interpersonal sebelum dan setelah diberikan layanan bimbingan pribadi-sosial. Dengan demikian terdapat perubahan komunikasi interpersonal peserta didik, yang semula dalam kriteria rendah dan sangat rendah meningkat menjadi kriteria sedang dan tinggi setelah diberikan perlakuan.

Berdasarkan tabel uji t-test diketahui bahwa peningkatan komunikasi interpersonal rata-rata 53.2 dari sekor rata-rata secara keseluruhan. Peningkatan tertinggi dialami oleh AY dengan beda sekor sebesar 59 dan peningkatan terendah dialami oleh IND dan TT yang hanya sebesar 50 dari sekor prettest. Namun secara keseluruhan kesepuluh peserta didik mengalami kenaikan dari kriteria rendah dan sangat rendah menjadi sedang dan tinggi.

Kenaikan sekor yang hanya mencapai tingkat kiteria sedang dikarenakan beberapa hal, diantaranya yaitu waktu pelaksanaan layanan bimbingan pribadi-sosial yang dilakukan denngan waktu yang singkat, ruangan yang panas menjadi penyebab kurang efektifnya pelaksanaan pelaksanaan layanan bimbingan pribadi-sosial. Hal tersebut berdampak kurang optimalnya pelaksanaan layanan bimbingan pribadi-sosial dan berdampak kepada hasil yang diperoleh dalam upaya meningkatkan komunikasi interpersonal peserta didik.

Selain faktor diatas juga terdapat faktor sosio-culture dimana kebiasaan peserta didik kelas XI SMA Negeri 2 Padang Cermin masih banyak menganggap bahwa membicarakan masalah pribadi yang dialami merupakan hal yang tidak etis dirasakan peneliti sebagai faktor penghambat yang cukup berpengaruh terhadap kurang optimalnya layanan bimbingan pribadi-sosial, walaupun pada akhirya peneliti mampu mengatasi, akan tetapi butuh waktu yang cukup lama untuk melakukannya.

Meskipun penelitian ini telah tercapai dilaksanakan sebaik mungkin, akan tetapi penelitian ini memiliki keterbatasan. Berikut ini adalah keterbatasan peneliti:

1) Layanan bimbingan pribadi-sosial yang dilaksanakan sebanyak sepuluh kali pertemuan selama kurang lebih satu bulan sebenarnya dirasa kurang maksimal. Karena hasil dari proses layanan bimbingan pribadi-sosial yang maksimal tidak bisa dilakukan secara instan, apalagi dalam hal ini untuk meningkatkan komunikasi interpersonal. Komunikasi interpersonal perlu dikontrol dari waktu ke waktu.

2) Waktu pelaksanaan layanan bimbingan pribadi-sosial kurang efektif karena hanya 45 menit karena peserta didik masih terikat pada saat jam sekolah.

3)

Untuk pengecekan perubahan perilaku klien hanya menggunakan skala efektivitas komunikasi interpersonal. Perilaku peserta didik selama di dalam kelas dan di sekolah tidak bisa teramati secara langsung dan hal ini bisa menjadikan terjadinya bias 


\section{Simpulan dan Saran}

Berdasarkan hasil penelitian yang diperoleh, dapat diketahui bahwa hasil penelitian menunjukan bahwa komunikasi interpersonal peserta didik di SMA Negeri 2 Padang Cermin dapat ditingkatkan melalui layanan bimbingan pribadi-sosial. Maka dapat disimpulkan bahwa layanan bimbingan pribadi-sosial efektif dalam meningkatkan komunikasi interpersonal pesertadidikkelas XI SMA Negeri 2 Padang CerminKabupatenPesawaran.

Hal ini ditunjukan dari hasilpengujian hipotesis dengan menggunakan uji t (t-test), dari hasil pretest dan posttest yang diperoleh pada kelompok eksperimen $\mathrm{t}$ hitung $=50.250>\mathrm{t}$ tabel $0.05=2.262, \mathrm{df}=\mathrm{n}-1=10-1=9$ dengan $\mathrm{P}$ value $<\mathrm{t}$ tebel $(0.000<0.005)$, maka Ho ditolak dan Ha diterima yang bermakna layanan bimbingan pribadi- sosial dapat digunakan untuk meningkatkan komunikasi interpersonal peserta didik.

Secara keseluruhan penelitian ini meghasilkankesimpulan bahwa layanan bimbingan pribadi-sosial dapat meningkatkan komunikasi interpersonal peserta didik di SMA Negeri 2 Padang Cermin ditandai dengan adanya peningkatan dalam berkomunikasi peserta didik. Hal ini dapat dilihat dari perbedaan dan perbandingan antara hasil belajarpretest danposttest hasil belajar.

Berdasarkan hasil penelitian ini dibuktikan dengan adanya perubahan peserta didik yang dikategorikan dalam komunikasi interpersonal rendah setelah diberikan layanan bimbingan pribadi- sosial dengan memanfaatkan dinamika konseling kelompok, maka ada beberapa saran yang dapat digunakan sebagai bahan pertimbangan yaitu:

1. Peserta didik diharapkan dapat terus berusaha mengembangkan dan meningkatkan komunikasi interpesrsonal, dan juga memperbanyak wawasan tentang bagaimana meningkatkan komunikasi interpersonal yang baik. serta mencapai kesejahteraan diri dengan menjalin hubungan sosial yang baik dengan lingkungan sekitar.

2. Guru bimbingan dan konseling diharapkan agar dapat memprogramkan dan melatih peserta didik dengan melaksanakan pelayanan bimbingan dan konseling sesuai dengan kurikulum yaitu untuk mengatasi permasalaha- permasalahan yang terjadi pada peserta didik, terutama pada peserta didik yang dikategorikan memiliki masalah dalam komunikasi interpersonaldan dalam hubungan sosialnya.

3. Kepala sekolah agar dapat merumuskan kebijakan dalam memberikan dua jam pelajaran efektif masuk kelas untuk layanan bimbingan dan konseling sesuai dengan model pembelajaran bermutu

4. Untuk peneliti lebih lanjut, diharapkan dapat melakukan penelitian yang lebih luas dan komprehensif mengenai layanan bimbingan pribadi-sosial dalam menangani peserta didik yang memiliki kategori komunikasi interpersonal rendah dan perlu diadakannya layanan bimbingan dan konseling individu maupun kelompok untuk mengetahui masalah-masalah terkait pada peserta didik yang memiliki masalah dalam komunikasi secara lebih mendalam

\section{Daftar Pustaka}

Ahmad Juntika Nurihsan. 2014. Bimbingan dan Konseling. Bandung: Refika Aditama.

Ainur Rohim Faqih. 2011. Bimbingan dan Konseling dalam Islam. Yogyakarta: UII Press.

Anas Sudijono. 2012. Pengantar Statistik Pendidikan. Jakarta: PT. Grafindo Persada.

Anwar Sutoyo. 2012. Pemahaman Individu. Yogyakarta : Pustaka Pelajar.

Arikunto Suharsimi. 2010. Prosedur Penelitian Suatu Pendekatan Praktik. Jakarta: PT. Rieneka Cipta.

Azwar Saifuddin. Penyusunan Psikologi Edisi 2. Yogyakarta: Pustaka Pelajar. 
Depag RI. 2006. Al-Qur'an dan Terjemahannya. Bandung: CV.Diponegoro.

Dewa Ketut Sukardi. 2002. Pengantar Pelaksanaan Program Bimbingan dan Konseling di Sekolah. Jakarta: PT. Rieneka Cipta.

Dian Wisnu Wardani \& Sri Fatmawati. 2012. Hubungan Interpersonal. Jakarta: Salemba Humanika.

Eko Putro Widiyoko. 2014. Penelitian Hasil Pembelajaran di Sekolah. Yogyakarta: Pustaka Pelajar.

Farid Mashudi. 2012. Psikologi Konseling. Yogyakarta: Salemba Humanika.

Herdiansyah Pratama. "Pola Hubungan Komunikasi Interpersonal Antara Orang Tua dengan Anak Termotivasi Berprestasi Pada Anak" (On-Line), Tersedia id://repository.uinjkt.ac.i/dspace/beitstream/123456/1854/I/HERDIANSYAH\%20PR ATAMA-FDK.pdf (14 April 2015.

Ingrit Nanisrinuria. 2013. "Program Bimbingan dan Konseling Pribadi Sosial Untuk Meningkatkan Kemampuan Komunikasi Siswa”. Skripsi Program Stara 1 Universitan Pendidikan Indonesia, Bnadung.

Isnaini Maulina Putri. 2015 "pelaksanaan layanan bimbingan pribadi-sosial dengan teknik latihan asertif pada peserta didik terisolir kelas ix madrasah tsanawiyah muhammadiyah sukarame bandar lampung. .Jurnal Skripsi Program Stara 1 IAIN Raden Intan Lampung.

Martin Handoko \& Theo Riyanto. 2014. Bimbingan dan Konseling di Sekolah. Yogyakarta. Kanisius.

Mohammad Nuh, Permendiknas No. 111 Tahun 2014, http:// permendikbud-no-111-tahun2014-tentang-bimbingan-dan-konseling.pdf-adobe reader. diakses Jum'at, 27 Februari 2015 pukul 10:20 WIB.

Muhammad Ahdiyat. 2013 "Meningkatkan Efektivitas Komunikasi Antar Pribadi Melalui Layanan Konseling Kelompok", Jurnal Skripsi Program Stara 1 Universitas Negeri Semarang UNNES. Semarang.

Pengertian Komunikasi (On-Line), tersedia di: https://id.m.wikipedia.org/wiki/komunikasi (13 April 2015).

Prayitno \& Erman Amti. 2004. Dasar-Dasar Bimbingan dan Konseling. Jakarta: PT. Rieneka Cipta.

Putri Paradise Atmaja. 2015."Pengaruh Konseling Behavior dalam Keterampilan Komunikasi Antar Pribadi”. Jurnal Skripsi Program Stara 1 IAIN Raden Intan Lampung.

Rifda EL Fiah. Layanan Bimbingan dan Konseling di Sekolah. Bandar Lampung: IAIN Raden Intan Lampung.

Samsul Munir Amin. 2010. Bimbingan dan Konseling Islam. Jakarta: Amzah.

Sarlito W. Sarwono \& Eko A Mainarno. 2009. Psikologi Sosial. Depok: Salemba Humanika.

Slamet Santoso. 2014. Teori-Teori Psikologi Sosial. Bandung: PT. Refika Aditama.

Sugiyono. 2014. Metode Penelitian Majagemen. Bandung: Alfabeta.

Sugiyono. Metode Penelitian Kuantitatif, Kualitatif dan R\&D.

Sumadi Suryabrata. 2011. Psikologi Pendidikan. Jakarta. PT. Grafindo Persad. 
Tohirin. 2009. Bimbingan Konseling di Sekolah dan Madrasah Berbasis Intelegensi. Jakarata: Rajawali Pers.

Zainal Aqib. 2012. Bimbingan dan Konseling di Sekolah. Bandung: Yrama Widya. 
